\title{
Początki polskiego chrześcijaństwa na podstawie Kroniki to jest historyi wszytkiego świata... Marcina Bielskiego ${ }^{1}$
}

\section{Beginnings of Polish Christianity based on Kronika, to jest historyja wszytkiego świata written by Marcin Bielski}

\author{
Dorota Kozaryn \\ Wydział Filologiczny, Uniwersytet Szczeciński, \\ Aleja Piastów 40b, 71-064 Szczecin, Polska; \\ e-mail: dorota.kozaryn@usz.edu.pl
}

\begin{abstract}
Abstrakt
Artykuł zawiera prezentację sposobu opisywania chrztu Polski w trzecim wydaniu (1564) Kroniki to jest historyi wszytkiego świata... Marcina Bielskiego. Przedstawienie zawartości treściowej właściwego fragmentu Kroniki stało się podstawą analizy słownictwa religijnego oraz wyróżników składniowych tekstu Bielskiego.
\end{abstract}

Słowa kluczowe: językoznawstwo historyczne; Marcin Bielski; słownictwo religijne.

\begin{abstract}
This paper comments on the manner of describing the baptism of Poland in the third edition of Kronika, to jest historyja wszytkiego świata written by Marcin Bielski (1564). Presenting the textual contents of the specific passage of Kronika... has resulted in an analysis of the religious vocabulary and syntactical discriminants of Marcin Bielski's text.
\end{abstract}

Keywords: historical linguistics; Marcin Bielski; religious vocabulary.

Celem poniższych uwag jest ukazanie sposobu przedstawienia początków chrześcijaństwa w Polsce w wieku XVI, „złotym wieku” polskiej kultury. Źródłem egzemplifikacji jest Kronika, to jest historyja świata... Marcina Bielskiego, zdaniem Mirosława Korolki „najokazalszy przykład sarmackiej twórczości dziejopisarskiej” (Korolko 1991: 452), pierwszy, a na pewno - jak twierdzą historycy literatury - pierwszy znany drukowany w języku polskim encyklopedyczny zarys popularnej wiedzy o ówczesnym świecie i jego początkach (Chrzanowski 1926: 129). Marcin Wolski-Bielski żyjący w latach 1495-1575, ziemianin, którego do samokształcenia zachęcił pobyt na dworze wojewody krakowskiego, marszałka wielkiego koronnego Zygmunta Starego, Piotra Kmity z Wiśnicza, publikował

${ }^{1}$ Artykuł przygotowany w ramach grantu Narodowego Programu Rozwoju Humanistyki nr rej. 11H13030282 Marcin Bielski „Kronika to jest historyja świata...” (1564) - edycja dzieła. 
swoją Kronikę trzykrotnie w latach: 1551, 1554 i 1564, każde kolejne wydanie zmieniając i rozbudowując. Częścią, którą autor poprawiał w poszczególnych wydaniach najmniej była ta dotycząca spraw polskich, zwana przez badaczy spuścizny Bielskiego kronika polska, w wydaniu z 1551 roku obejmująca więcej niż połowę całości Kroniki świata, „prawie niezmieniona” (Korolko 1991: 453) w wersji z 1554 roku, zaś w wydaniu z 1564 roku uwzględniająca jako ostatnie wydarzenie śmierć wcześniejszego protektora Piotra Kmity w roku 1553 i stanowiąca księgę ósmą (k. 333-425v) z dziesięciu budujących ostatnie za życia autora wydanie Kroniki. Ignacy Chrzanowski poszukując przyczyn umieszczenia przez Bielskiego w Kronice to jest historyji świata oddzielnej księgi poświęconej historii ojczystej, stwierdził, że ,pobudką [...] do napisania kroniki polskiej [...], była miłość ojczyzny. Chodziło Bielskiemu mianowicie o sławę narodu polskiego [...]. A drugą pobudką było to samo, co przy pisaniu Kroniki świata: wgląd dydaktyczny; nie tylko bowiem od ludzi obcych, ale i od własnych przodków można się bardzo wiele nauczyć" (Chrzanowski 1926: 101). Dariusz Śnieżko zauważa, że stosowana przez Bielskiego „metoda doboru informacji wyraźnie wskazuje na «polonocentryczność» kroniki świata. Ujawnia się ona zarówno w materiale uwzględnionym, jak i pominiętym, czyli w tym, co rodzimego czytelnika mogło zainteresować, a co nie” (Śnieżko 2004: 78). To dowodzi, że nie mógł Bielski, pisząc swoją Kronikę dla przeciętnego szlachcica-ziemianina, bez humanistycznego wykształcenia i znajomości łaciny, zainteresowanego jednak dawnymi dziejami świata ${ }^{2}$, pominąć tego, co dotyczyło Polski, począwszy od jej legendarnych dziejów a skończywszy na czasach sobie współczesnych.

Nie ukrywa Bielski tego, że pisząc swoją Kronikę, wykorzystywał prace innych dziejopisów, nie była więc jego najobszerniejsza księga „,dziełem oryginalnym, tzn. nie opierała się na samodzielnych badaniach źródeł historycznych. Była to kompilacja oparta na kilku wydanych drukiem za granicą opracowaniach dotyczących historii powszechnej, którą już w pierwszej fazie rozwoju kultury renesansowej kultywowano w różnych krajach zachodniej Europy" (Korolko 1991: 454). Do informacji M. Korolki dodać należy, że tak samo postępował Bielski, konstruując kronikę polską. I. Chrzanowski, zestawiając tekst Bielskiego ze wskazanymi przez niego samego źródłami ${ }^{3}$, udowodnił, że

2 Tak opisuje adresata Kroniki M. Korolko (1991).

3 „Tu zaprawdę inaczej będzie, aniż tak byli chytrzy kronikarze naszy pierwszy, i owszem więcej i dłużej pisali o przeciwnym szczęściu starszych naszych, niżli o fortunie ich. Pisali też rzeczy wiele niepotrzebnych, jako o fundacjach kościelnych, prebend, klasztorów, wsi klasztorne, i gdziekolwiek dziesięciny mają, co tu nie miało nic czynić. Pisali o nas postronni ludzie uczeni więcej niż my sami o sobie, i lepiej, jako Prokopius cesarski Grek, po nim Blondus, Silwijus, Sabellikus, Krancyjus, Sakso: Jowijus, ktorych doktor Kromer używał w pisaniu swojej kroniki nowo wydanej, z pilnością sie wywiadując początku a wywodu naszego słowieńskiego języka, lecz sie w tym barzo nie zgadzają historykowie z naszymi starymi kronikarzami, jako będzie niżej trochę o tym. Pisali też drudzy postronni historykowie o nas nie trafnie, jako Eneas Sylwijus, i drudzy za nim, mając nas za opiłe ludzi” (Bielski 1564: 334). Na k. 338 Bielski jeden z fragmentów rozpoczyna tytułem: Bernat 
kronika polska [Bielskiego - dop. D.K.] składa się z czterech części: pierwsza (do roku 1506) jest streszczeniem Miechowity ${ }^{4}$, uzupełnionem (!) kilku szczegółami, wziętymi z Wapowskiego ${ }^{5}$ i Długosza; druga (1507-1516) - streszczeniem Decjusza ; źródłem trzeciej (1517-1535) są notatki z Wapowskiego i własne wiadomości; czwarta (1536-1548) powstała z własnych notatek autora, z powieści ludzkiej i z autopsji. Dwie pierwsze opracował Bielski wcale szczegółowo, mając w czasie pisania obszerne źródła przed oczami (Chrzanowski 1926: 119).

Sprawdźmy więc, jak to „wcale szczegółowe” opracowanie polskich dziejów najdawniejszych przedstawia początek chrześcijaństwa w Polsce.

Po raz pierwszy o chrzcie w kontekście Polski wspomina się przy wydarzeniach umieszczonych przez Bielskiego pod datą 921 lata od Bożego narodzenia (k. 343) ${ }^{7}$. Opisuje tu Bielski historię rodzinną księcia Ziemomysława, któremu urodził się niewidzący syn. Podczas mianowania i postrzygania dziecka w Gnieźnie (wezwali go Ziemysław - k. 343) niewidomy przejrzał. Zaintrygowany tym ociec Leszko ${ }^{8}$, który często sie wywiadowat od wieszczkow co sie $w$ tym dzieje, iż go tak bogowie w synie pocieszyli znamienicie (k. 343), uzyskał odpowiedź iż rychło Pan Bog Polskę oświeci z łaski swej jako to dziecię (k. 343). Następnie Bielski objaśnia myśli pytającego: On mnimał by to ku świeckiej chwale szło (k. 343) i przedstawia właściwe rozumienie tego zdarzenia, które się zrealizowało potem: ano iz krztem świętym mieli być oświeceni przez tego Mieszka, jako tak było (k. 343). W pierwszym zdaniu fragmentu opatrzonego datą lata od narodzenia Pańskiego 962. (k. 343v) dowiadujemy się, że ślepo urodzon (k. 343v) był Mieszko i dlatego takie otrzymał imię: a pierwej Mieszko był rzeczony od zamieszania rze-

Wapowski kanonik krakowski tak swoję kronikę poczyna, przywołując tym samym kolejne źródło danych dotyczących wydarzeń polskich.

${ }^{4}$ Mowa o Chronica Polonorum wydanej po raz pierwszy w 1519 roku, napisanej przez Macieja z Miechowa, żyjącego w latach 1457-1523, pierwszych drukowanych dziejach Polski po łacinie [dop. D.K.].

${ }^{5}$ Chodzi o łacińską Kronikę Bernarda Wapowskiego, kanonika katedry krakowskiej, żyjącego w latach 1450-1535, która będąc kompilacją prac J. Długosza, Miechowity i J.L. Decjusza, została wydana we fragmencie dotyczącym lat 1506-1535 w Kolonii w 1589 roku. I. Chrzanowski pisze, że twierdzenie jakoby I część Kroniki Wapowskiego (do 1380 roku) przetrwała dzięki temu, że Bielski przełożył ją/ streścił w swojej Kronice jest błędne, miał bowiem Bielski przede wszystkim w tym zakresie czasowym korzystać z Miechowity, co udowadnia zestawienie fragmentów Miechowity i Bielskiego (por. Chrzanowski 1926: 105, 108, 314-317) [dop. D.K.].

${ }^{6}$,Jodok Ludwik Decjusz (ok. 1485-1545), spolszczony Niemiec z Alzacji, historyk i ekonomista [...], opublikował u Wietora przy dziele Miechowity swój historyczny traktat w trzech częściach: I De vetustatibus Polonorum (O starożytnościach Polaków), II De Iagellonum familia (O rodzie Jagiellonów), III De Sigismundi regis temporibus (O czasach króla Zygmunta). Część pierwsza i druga jest kompilacją, trzecia - najcenniejsza - oryginalnym opracowaniem wydarzeń znanych autorowi bezpośrednio, doprowadzonym do 1516 r." (Ziomek 2006: 160).

7 Jeśli nie podano inaczej cytaty, pochodzą z wydania trzeciego kroniki M. Bielskiego (bibliografia). Po cytacie w nawiasie podaje się numer strony.

${ }^{8}$ Pojawienie się imienia Leszko wydaje się pomyłką - to dziadek ślepo urodzonego Ziemysława, ojciec Ziemomysława. 
czy pospolitej, gdy sie ślepo urodzit (k. 343v). Nie wspomina Bielski o innym niewidomym synu jakiegokolwiek księcia, nie wyjaśnia także w żaden sposób tej informacji (wcześniej pisał przecież o niewidomym Ziemysławie). Próbuje jednak wskazać powód, dla którego Mieszko pełniący władzę dzięki wyborowi po ojcu na monarchija polska (k. 343v), postanowił się ochrzcić. Uzasadnienie - zdaniem Bielskiego - tkwi w niepowodzeniach prokreacyjnych księcia, który mimo posiadania siedmiu miłośnic nie doczekał się potomstwa, stąd bywat smutny (k. 343v). Poradzono mu wtedy chrzest: Przeto byt namawian od niektorych krześcijan aby sie okrzcił chceli potomki mieć (k. 343v). Mieszko postanowił wcielić radę w życie: Postat do Czech po core krola Bolestawa co brata Wactawa byt zabit, imieniem Dąbrowke. Krol czeski przyzwolit tym obyczajem jesli sie chce okrzcić. Uczynit to Mieszko rad, okrzcit sie lata od narodzenia Pańskiego 965. w Gnieźnie, tam go mianowano Miecsław od sławy dobrej (k. 343v). Chrzest poddanych Mieszka natomiast to efekt jego nakazu, którego realizacji przypisano nie tylko konkretną datę, ale i dookreślono jego okoliczności: Przykazal też wszytkim tak bogatym jako ubogim aby sie pokrzcili siódmego dnia marca, wmiotawszy wogień batwany drzewiane, a kamienne pottukszy do wody (k. 343v-344). To w ostatnim z przywołanych wydarzeń upatruje Bielski źródeł trwającego do jego czasów zwyczaju: A stąd jeszcze dziś ten obyczaj mają w Wielkiej Polsce $i$ w Ślasku, iż siódmego dnia marca topia Marzanę ubrawszy jako niewiastę, wyszedszy ze wsi śpiewajac: Śmierć sie wije po płotu szukajęcy kłopotu etc. (k. 344). Próbuje także ukazać wcześniejsze wierzenia poddanych Mieszka: Bo przed tym leda co chwalili: planety, Pogody, Pogwizdy, Heli, Lede, Dziewanne, to jest Dyjanę, Marzane, i wiele takich (k. 344). By podkreślić wierność Mieszka wierze chrześcijańskiej przytacza Bielski wprowadzony przez księcia zwyczaj: Na znak dobrego krześcijaństwa ustawił Mieszko, aby gdy czciono we mszy Ewanjelia święta, każdy do put (!) miecza dobyt, będac gotów umrzeć o wiarę krześcijańska (k. 344). Autor uznał za istotną także działalność założycielską Mieszka: Założyt też dwa kościoty arcybiskupie: jeden w Gnieźnie, drugi na zamku S. Wacława $k$ woli krolowej Dąrowce na pamiątkę stryja jej Wacława, którego byt ociec zabit. Zbudowat też biskupi kościoł w Kruszwicy, ale potym przeniesion do Wtoctawia nad Wistę. Wiele innych kościołow pobudowat i nadat znamienicie, tak sam jako żona jego (k. 344). W ostatnim akapicie fragmentu opatrzonego rokiem 992. jednak ukazuje Bielski, że chrześcijaństwo w Polsce jeszcze nie zostało w tym czasie utrwalone, skoro nawet Mieszko nie w pełni jest chrześcijaninem. Tak można zinterpretować informację o misji biskupa krakowskiego Lamperta, który byt posłan do Rzyma od Miecsława proszac o korone krolestwu polskiemu, ale obiecawszy zasie jej odmowit rzekąc: Jeszcze jej nie godzien, mnimając go jeszcze nie być prawym krześcijaninem (k. 344).

Nie jest zadaniem niniejszych uwag porównywanie przedstawienia Bielskiego z wiedzą historyczną, nie sposób jednak nie zwrócić uwagi na datę chrztu Miesz$\mathrm{ka}$ - tak jak Miechowita Bielski podaje, że miało to miejsce w roku 965. Czy to potwierdzenie opinii D. Śnieżki, że obok niekonsekwencji nazewniczych osobo- 
wych (Ziemysław to Mieszko, który na chrzcie otrzymuje imię Miecsław), „W sprawach chronologicznych nie był Bielski skrupulantem” (Śnieżko 2004: 155), czy też raczej ukazanie, że od chrztu władcy do chrztu poddanych upłynął rok? Co do tej kwestii także współcześni historycy nie mają pewności. Dodać jedynie należy, że w Kronice polskiej Marcina Bielskiego nowo przez Joachima Bielskiego, syna jego wydanej już po śmierci ojca w 1597 roku jako rok chrztu Mieczsława pojawia się 966, na marginale w postaci: Roku 966 krzest s. naszy przyjęli (Kronika 1597: 49). Nie udało się jednak dotychczas ustalić, co w tym utworze jest dziełem ojca, co natomiast syna, który starał się za wszelką cenę spowodować, by dzieło ojca nie straciło na popularności z powodów wyznaniowych $^{9}$, do tego wątku wypadnie jeszcze powrócić.

Po zapoznaniu się z prezentacją zawartości treściowej opisu chrztu w Kronice Marcina Bielskiego, pora przyjrzeć się jego językowemu kształtowi. Najpierw kwestia leksyki, którą można określić mianem religijnej. W przywołanym powyżej fragmencie za słownictwo religijne uznać należy leksemy związane zarówno z nowo wprowadzaną religią, jak i wcześniejszymi wierzeniami poddanych Mieszka. Do grupy słownictwa religijnego chrześcijańskiego należą wyrazy dotyczące pierwszego sakramentu i jego przyjmowania: krzest, okrzcić się, pokrzcić się, oraz wyznawanej religii: krześcijanin, krześcijański, krześcijaństwo; określenie świątyni: kościót; nazwa przełożonego gminy chrześcijańskiej biskup i pochodzący od niego przymiotnik: biskupi oraz przymiotnik arcybiskupi; nazwa nabożeństwa: msza i czytanej podczas jego trwania fragmentu Dobrej Nowiny: Ewanjelija; a także wyrazy: wiara, chwalić w znaczeniu 'wyznawać, wielbić, czcić'; Pan Bóg, święty, które zostały przez chrześcijaństwo „przysposobione”, wykorzystane po doprecyzowaniu ich znaczeń. Pojawienie się większości słownictwa nazwanego tu chrześcijańskim w polszczyźnie to efekt zapożyczania wyrazów pochodzenia łacińskiego lub greckiego przez język niemiecki i/ lub czeski, z których to języków trafiły w dwóch okresach: 950-1050 oraz XIV-XVI w. (Czarnecki 1999: 15) do języka polskiego. O pochodzeniu słownictwa chrześcijańskiego w polszczyźnie pisano wielokrotnie (Klich 1927; Lisowski 1993; Kreja red. 1999), zauważyć więc tu jedynie wypada wykorzystaną przez Bielskiego postać fonetyczną wyrazów dotyczących chrztu. Funkcjonująca w Kronice forma

\footnotetext{
9 „Wszystkie te proreformacyjne akcenty kroniki polskiej Marcina Bielskiego zostały usunięte bądź wyraźnie stonowane przez syna pisarza, Joachima, który już jako prawowierny katolik wydał w 1597 r. pod nazwiskiem ojca i swoim księgę zatytułowaną: Kronika polska Marcina Bielskiego nowo przez Joachima Bielskiego, syna jego wydana. Bardzo trudno jest jednak przeprowadzić dziś dokładne rozgraniczenie własności ojca od syna. W grę bowiem wchodzą nie tylko korekty jej pierwotnie proreformacyjnego charakteru, ale również uzupełnienia materiałowe czy sprostowania faktograficzne w stosunku do wydania z 1564, gdy wchodziła w skład Kroniki wszytkiego świata. Pracę tę mógł wykonać jeszcze Marcin Bielski, który - wedle świadectwa syna - do końca swoich dni zajmował się pisaniem kroniki, względnie czynność tę wykonywał Joachim pod kontrolą ojca" (Korolko 1991: 460-461).
} 
z nagłosowym $k$ - była - jak wynika z danych SPXVI ${ }^{10}$ - dominująca w szesnastowiecznej polszczyźnie, co zapewne wynika z przejęcia tej grupy wyrazowej w takiej właśnie postaci z języka czeskiego (staroczeskie: krest, křtiti : křstiti (/ krstiti), křest'an) (Boryś 2005: 70-71). Wyjątek stanowi tu wyraz krześcijanin, który według danych SPXVI wystąpił w tekstach szesnastowiecznych prawie tak samo często jak forma $\mathrm{z} c h$ - $\left(823: 825^{11}\right)$. Jeśli chodzi o słownictwo religijne niechrześcijańskie przede wszystkim wskazać należy nazwy bóstw zaczerpnięte z kroniki Długosza: Pogoda ${ }^{12}$, Pogwizd ${ }^{13}$, Dziewanna ${ }^{14}$, Marzana ${ }^{15}$, Lada, a właściwie $Ł a d a^{16}$, niewystępująca u Długosza Hela, [chyba że chodziło Bielskiemu o Helice, czyli gwiazdozbiór Wielkiej Niedźwiedzicy], określenia obiektów kultu: planeta jako 'ciało niebieskie, mające wpływ na życie ludzkie' oraz bałwan drzewiany i kamienny jako 'wyobrażenie bóstwa, któremu oddawana jest cześć' - por. hasło: batwan (SPXVI 1966: 1, 294). Pod względem leksykalnym więc nie możemy wskazać wykorzystania elementów nowych, nietypowych dla ówczesnej polszczyzny, wyróżniających w jakikolwiek sposób Bielskiego na tle innych literatów XVI wieku. Warto zatem przyjrzeć się ukształtowaniu składniowemu fragmentu Kroniki dotyczącego chrztu Mieszka i jego poddanych. Zacznijmy od rodzajów zdań. Wśród 19 zdań ${ }^{17}$ budujących opisywany fragment, 13 stanowią różnorodne zdania złożone podrzędnie, 4 - złożone współrzędnie oraz 2 zdania proste rozwinięte, co odpowiednio stanowi $68,4 \%, 21,1 \%$ oraz $10,5 \%$ wszystkich zdań i potwierdza wyniki analiz Anny Wierzbickiej, która wskazała, że 79\% zdań w szesnastowiecznej prozie narracyjnej stanowią zdania złożone podrzędnie (1966: 234). Liczba zdań składowych to najczęściej dwa (tak w ośmiu wypowiedzeniach), trzy wypowiedzenia zbudowane są z trzech zdań składowych, po dwa zdania - z czterech, pięciu i siedmiu, co średnio stanowi 3,3 członu w zdaniu złożonym. Wśród zdań złożonych przeważają bezspójnikowe, choć te spójniki, które są wykorzystywane: przeto, aby, $g d y, i z$, bo, ale, $i, a$, jeśli nie są współfunk-

${ }^{10}$ Hasło: krzest - na 971 użyć 665 z nagłosowym $k$ - wobec 306 z ch- (SPXVI 1978: 11, 307-311); hasło: krześcijański - na 2829 użyć 1668 z nagłosowym $k$ - wobec 1161 z ch- (SPXVI 1978: 11, 314-322); hasło: krześcijaństwo - na 346 użycia 227 razy z nagłosowym $k$ - wobec 119 z ch- (SPXVI 1978: 11, 322-323); hasło: okrzcić się - na 102 użycia 70 w postaci okrzcić się, 25 ochrzcić się, 4 razy jako okrcić się, 3 razy jako ochrcić się (SPXVI 1992: 21, 298); hasło: pokrzcić się - wśród 26 użyć 25 z $k$ - tylko 1 z ch- (SPXVI 1998: 26, 387).

${ }^{11}$ Hasło: krześcijanin (SPXVI 1978: 11, 311-314).

12 „Nazwa rzekomego bóstwa w mitologii słowiańskiej, wymienionego przez Długosza”. Za: SPXVI 1998: 26, 170.

13 „Nazwa słowiańskiego bóstwa wiatru”. Za: SPXVI 1998: 26, 201.

${ }^{14}$ „W mitologii słowiańskiej bogini na wzór rzymskiej Diany”. Za: SPXVI 1972: 6, 438.

15 „Przejęte od Długosza imię rzekomego bóstwa starosłowiańskiego, odpowiadającego rzymskiej Cererze". Za: SPXVI 1981: 13, 185.

16 „Wymyślona przez Jana Długosza bogini słowiańska, której imię zaczerpnął [...] z przyśpiewów staropolskich pieśni wiosennych, [...], uważając ją za inwokację do dawnego bóstwa słowiańskiego”. Za: Kopaliński 2003: 690.

${ }^{17} \mathrm{Za}$ zdanie uznaję fragment tekstu rozpoczynany wielką literą, kończący się kropką. 
cyjne. Spośród członów składowych wiele ma charakter imiesłowowy (np. ubrawszy jako niewiastę, wyszedszy ze wsi śpiewają - k. 344; proszą o korone krolestwu polskiemu, ale obiecawszy - k. 344; będac gotow umrzeć o wiarę krześcijańska - k. 344), wyraźnie także wprowadza się przytoczenia: zasię jej odmowit rzekac: Jeszcze jej nie godzien (k. 344). W pięciu zdaniach na dziewiętnaście ostatnim elementem zdania jest forma czasownikowa (Mieszko ktory byt ślepo urodzon, po ojcu swym na monarchija polska wybran - k. 343v; Przeto byt namawian od niektorych krześsijan aby sie okrzcit chceli potomki mieć - k. 343v; Krol czeski przyzwolit tym obyczajem jesli sie chce okrzcić - k. 343v; [...]gdy sie ślepo urodzit - k. 343v; [...] ktorego byt ociec zabit - k. 344), co wyraźnie wskazuje na tendencję przenoszenia orzeczenia do środkowej części zdania. Pojawia się także wykorzystanie połączenia biernika z bezokolicznikiem, łacińskie accusativus cum infinitivo: mnimając go jeszcze nie być prawym krześcijaninem (k. 344), realizowanej w typowy sposób - po verba sentiendi ${ }^{18}$. Zdarzają się też konstrukcje, łączące poszczególne człony w sposób dość skomplikowany - tzw. zdania rozerwane, np. ustawit Mieszko, aby gdy czciono we mszy Ewanjelia święta, każdy do put (!) miecza dobyt (k. 344). Mimo tego kompozycja całego fragmentu nie pozostawia nic do życzenia: istnieją nawiązania międzyzdaniowe ${ }^{19}$, podkreślające przedstawiony przez Bielskiego logiczny ciąg wydarzeń, wynikający po części oczywiście z kolejności wydarzeń historycznych, ale i ze starań autora, by powiązać przedstawiane dzieje sensownie - „mówić o jednym”: najpierw informacja o Mieszku jako wybranym na władcę, potem kwestia braku potomstwa jako powód przyjęcia chrztu, następnie stwierdzenie przyjęcia chrztu, zmiana imienia jako jego skutek, nakaz chrztu wobec wszystkich poddanych powiązany z niszczeniem bożków i opisem współczesnego Bielskiemu zwyczaju jako śladu dawnych - przywołanych - wierzeń poddanych Mieszka, następnie opis działań Mieszka wskazujących na szerzenie nowej wiary: ustanowienie zwyczaju wydobywania miecza, budowanie nowych kościołów przez księcia i jego żonę, po przywołaniu Dąbrówki informacja o tym, że urodziła syna, po czym zmarła i została pochowana w Gnieźnie. Stąd drugi ożenek Mieszka z Judyt córką księcia węgierskiego i drugi syn. I wreszcie informacja o wysłaniu biskupa krakowskiego

18 „Słuszny jest tedy wniosek (Kropaczek), że ta konstrukcja biernika z bezokolicznikiem jest wynikiem wpływów łacińskich i niewolniczym naśladowaniem konstrukcji tzw. accusativus cum infinitivo. Potwierdza takie przypuszczenie ta okoliczność, że w XVI w. najczęstsze przykłady spotykamy u pisarzy drugiej połowy tego stulecia: u Górnickiego, Marcina Bielskiego, Orzechowskiego, Stryjkowskiego, Bazylika" (Klemensiewicz, Lehr-Spławiński, Urbańczyk 1965: 436).

${ }_{19}$ Por. A stad jeszcze dziś ten obyczaj maja w Wielkiej Polsce i w Śląsku, iż siódmego dnia marca topia Marzane (k. 344) jako nawiązanie do ostatniej części zdania poprzedniego: wmiotawszy w ogień batwany drzewiane, a kamienne pottukszy do wody (k. 343v-344). Zaś kolejne zdanie: Bo przed tym leda co chwalili: planety, Pogody, Pogwizdy, Heli, Lede, Dziewanne, to jest Dyjane, Marzane, $i$ wiele takich (k. 344) to $\mathrm{z}$ kolei nawiązanie do zdania poprzedniego zawierającego opis topienia Marzanny. 
do Rzymu w celu podjęcia starań o koronę, nieudane dla Polski, ale udane dla króla Węgier $w$ ten czas.

Wskazane powyżej elementy ukształtowania składniowego fragmentu Kroni$k i$ Bielskiego potwierdzają, że uznawany za twórcę polskiej prozy historycznej autor ${ }^{20}$ pisał w sposób pozwalający uznać go za reprezentanta tego z dwóch nurtów stylistyczno-składniowych występujących $\mathrm{w}$ tekstach pisanych okresu średniopolskiego, który ,jest wytworem piśmiennictwa renesansowego, wiąże się z wzorami klasycznymi" (Długosz-Kurczabowa, Dubisz 2013: 459). Stwierdzenie to udowadnia spełnienie przez Kronikę Bielskiego (na przykładzie zaanalizowanego fragmentu) następujących wyznaczników tekstowych tego nowego pisanego stylu książkowego: „-- wyraźna segmentacja tekstu na wypowiedzenia [dzięki temu możliwe stało się wyodrębnienie poszczególnych zdań rozpoczynających się wielką literą i kończących się kropką - dop. D.K.]; - oszczędność i wystarczalność środków językowych [ogółem analizowany fragment składa się m.in. z 46 czasowników użytych ogółem 66 razy, 79 rzeczowników, z czego 31 to nazwy własne osobowe i miejscowe, użytych ogółem 114 razy, 25 przymiotników użytych 27 razy, 3 przysłówków użytych 4 razy - dop. D.K.]; - linearny układ składników wypowiedzenia [czego dowodzi choćby zdanie rozerwane opisywane powyżej - dop. D.K.]; - gramatyczność podmiotu [podmiot jest wyrażany rzeczownikiem w mianowniku - dop. D.K.]; - przesuwanie szyku orzeczenia do środka zdania [tak w 14 z 19 zdań - dop. D.K.]; [i już opisane powyżej - dop. D.K.]: - umiejętne stosowanie parataksy i hipotaksy; - celowe stosowanie imiesłowowych równoważników zdania; - staranne zewnętrzne (ponadzdaniowe) nawiązania wypowiedzeń w obrębie tekstu; - staranny dobór sfunkcjonalizowanych wskaźników zespolenia (spójników, zaimków względnych, partykuł); - oddzielanie mowy niezależnej i zależnej” (Długosz-Kurczabowa, Dubisz 2013: 459). Wszystkie te elementy zapewniają zrozumiałość, przejrzystość, ale i potoczystość stylu, rozumianą tu jako łatwość lektury.

Na zakończenie warto zwrócić uwagę na jeszcze dwie kwestie. Pierwsza z nich to swoista enigmatyczność opisu przebiegu chrztu: dowiadujemy się z Bielskiego, że chrzest jest oświeceniem i łaską; poznajemy powód, który skłonił Mieszka do jego przyjęcia i to, że wraz z przyjęciem chrztu Mieszko zmienił imię na Miecsław; nie wiemy natomiast nic na temat samego chrztu: czy polegał na całkowitym zanurzeniu w wodzie w specjalnie do tego sporządzonym naczyniu, czy na polaniu wodą, czy na uczynieniu znaku krzyża (gdyż tak należy - zdaniem Andrzeja Bańkowskiego - wyjaśniać pochodzenie słowa „krzest”21). Nie potrafię wyjaśnić, dla-

${ }^{20}$ Por. ,jako pierwszy trudził się nad zbudowaniem modelu polskiej prozy historycznej” (Śnieżko 2004: 239).

${ }^{21}$ Hasło chrzcić: „dyskusyjne czy jest to derywat od sb. starosłowiańskiego krbstb [...], może raczej zapożyczenie wprost ze st.-g.-nm. kristenen 'chrystianizować' (od kristen 'chrześcijanin', z łc. christianus). Tak czy inaczej słowo to jest świadectwem chrystianizacji Słowian metodą wojenną, polegającą na piętnowaniu znakiem Chrystusowym (krzyżem, wypalanym na skórze), wziętych do niewoli, by im utrudnić ucieczkę do swoich pogańskich rodaków. W tej sytuacji sam obrzęd sa- 
czego Bielski tak ograniczył swoją relację - czy dlatego, że uważał przebieg chrztu za oczywisty, czy może dlatego, że taką przyjął metodę opisu: gdy we wcześniejszych księgach przedstawiał przyjmowanie chrztu przez inne postaci historyczne, także nie opisywał samego procesu ograniczając się do stwierdzeń typu: przez wodny krzest (k. 138 v), okrzcit sie w imię Ojca i Syna, i Ducha Ś. (k. 149), aby nie krzczono ludzi jedno w sobote (k. 158), przy opisie historii biblijnych zrównując obmywanie się w wodzie z chrztem, np.: Judyt chodząc do wody umywała się (to jest krzcita) woda w rzece (k. $113 \mathrm{v})^{22}$.

I druga kwestia: wyznaniowy charakter całej Kroniki, a więc i sposobu przedstawienia chrztu Polski. W literaturze przedmiotu podnosi się protestancki charakter tego tekstu ${ }^{23}$, tak opisuje go M. Korolko:

wyraźniej niż w Kronice wszytkiego świata zaznaczy się w kronice polskiej krytycyzm i sceptycyzm Bielskiego wobec tradycji kościelnej, rodem z ducha reformacji, którym polski dziejopis był owładnięty, chociaż - jak wiadomo - nie opowiedział się za żadnym wyznaniem protestanckim. Postawę reformacyjną uwydatnia pisarz w swoistym antyklerykalizmie, atakowaniu chciwego na dobra materialne duchowieństwa, zwłaszcza zaś mnichów. Godzi się jednak przypomnieć, że w czasach przedtrydenckich, charakteryzujących się rzeczywistym obniżeniem poziomu intelektualnego i moralnego kleru katolickiego, wołanie o reformę było wówczas zjawiskiem powszechnym, rozpatrywanym zarówno przez myślicieli katolickich, jak i sympatyzujących z Lutrem czy Kalwinem. Kronika polska Bielskiego to jeden z wielu objawów i tekstowych dowodów tego krytycyzmu ideowego na gruncie polskim, korespondującego ze szlacheckim programem walki sejmowej, prowadzonej podczas tzw. sejmów egzekucyjnych, o likwidację nadmiernych przywilejów materialnych kleru (Korolko 1991: 460).

Nie podejmuje takiej krytyki Bielski w interesującym nas w niniejszych rozważaniach fragmencie. Nie wydaje się również, by brak uszczegółowionego opisu przebiegu przeprowadzania chrztu mógł świadczyć o tym, że przedstawienie

kramentalny zanurzania w wodzie (albo polewania nią lub tylko pokrapiania) wydawać się musiał nieistotny. [...]. W innych językach europejskich nazwy tej czynności sakramentalnej odbijają w sobie zanurzanie w wodzie [...]. Oficjalną chrześcijańską nazwa sakramentalnego zanurzenia było gr. baptizein (: báptein 'pogrążać, topić, tonąć, już u Homera także o zanurzaniu w zimnej wodzie gorącego przedmiotu metalowego dla zahartowania), stąd też łc. kośc. baptizāre "chrzcić" " (Bańkowski 2000: 1, 156).

${ }^{22}$ U Miechowity użyte są słowa: baptizare i ablutum, o tym obmyciu/ oczyszczeniu nie wspomina Bielski.

${ }^{23}$ Por. ,Ale najsilniejszym rysem indywidualnym i najznamienitszą cechą kroniki polskiej Bielskiego jest jego niechęć względem Kościoła katolickiego, uwydatniająca się niemniej wyraźnie, jak w Kronice świata, a jednocześnie pewien krytycyzm, a raczej sceptycyzm, względem tradycji kościelnej” (Chrzanowski 1926: 123). „Nastawienie proreformacyjne objawia się nie tylko na poziomie podstawowej zawartości dzieła - [...] Bielski zamieścił za Sleidanusem obszerną relację o rozwoju ruchu protestanckiego - ale także na poziomie drobnych a częstych komentarzy, aluzji i uszczypliwości, oddziałując też na sposób (niekiedy sceptyczny) pracy ze źródłami, w większości przecież prawowiernie katolickimi" (Śnieżko 2004: 78). 
chrztu Polski w księdze ósmej Kroniki wszytkiego świata Marcina Bielskiego jest nacechowane wyznaniowo.

\section{ŹróDeA}

Bielski M., 1564, Kronika, to jest historyja świata na sześć wiekow a czterzy monarchije rozdzielona z rozmaitych historykow tak w Świętym Piśmie krześcijańskim, żydowskim, jako i pogańskim wybierana i na polski język wypisana dostateczniej niż pierwej, z przydanim wiele rzeczy nowych. Od poczatku świata aż do tego roku, ktory się pisze 1564, z figurami ochędożnymi i własnymi, Kraków.

Kronika - Kronika polska Marcina Bielskiego nowo przez Joachima Bielskiego, syna jego wydana, Kraków 1597.

\section{Bibliografia}

Bańkowski A., 2000, Etymologiczny słownik języka polskiego, t. 1 A-K, Warszawa.

Boryś W., 2005, Stownik etymologiczny języka polskiego, Kraków.

Chrzanowski I., 1926, Marcin Bielski. Studium historyczno-literackie, wyd. 2 poprawione i rozszerzone, Lwów.

Czarnecki T., 1999, Najstarsze polskie stownictwo religijne o rodowodzie niemieckim, w: Tysiac lat polskiego słownictwa religijnego, red. B. Kreja, Gdańsk, s. 13-27.

Długosz-Kurczabowa K., Dubisz S., 2013, Gramatyka historyczna języka polskiego, wyd. 3, Warszawa.

Klemensiewicz Z., Lehr-Spławiński T., Urbańczyk S., 1965, Gramatyka historyczna języka polskiego, wyd. 3, Warszawa.

Klich E., 1927, Polska terminologia chrześcijańska, Poznań.

Kopaliński W., 2003, Słownik mitów i tradycji kultury, Warszawa.

Korolko M., 1991, Pionier sarmackiego dziejopisarstwa - Marcin Bielski, w: Pisarze staropolscy. Sylwetki, red. S. Grzeszczuk, t. 1, Warszawa.

Lisowski T., 1993, Cerkiew i kościót jako 'ecclesia' $i$ 'templum christianorum'w polszczyźnie szesnastowiecznej, w: Język a chrześcijaństwo, red. I. Bajerowa, M. Karpluk, Z. Leszczyński, Lublin, s. 131-144.

SPXVI - Słownik polszczyzny XVI wieku, t. I-XXXVI, red. M.R. Mayenowa, (później F. Pepłowski, K. Mrowcewicz), Wrocław-Warszawa-Kraków 1966 - Warszawa 2012. Śnieżko D., 2004, „Kronika wszytkiego świata” Marcina Bielskiego. Pogranicze dyskursów, Szczecin.

Kreja B. (red.), 1999, Tysiąc lat polskiego słownictwa religijnego, Gdańsk.

Wierzbicka A., 1966, System składniowo-stylistyczny prozy polskiego renesansu, Warszawa.

Ziomek J., 2006, Renesans, Warszawa. 